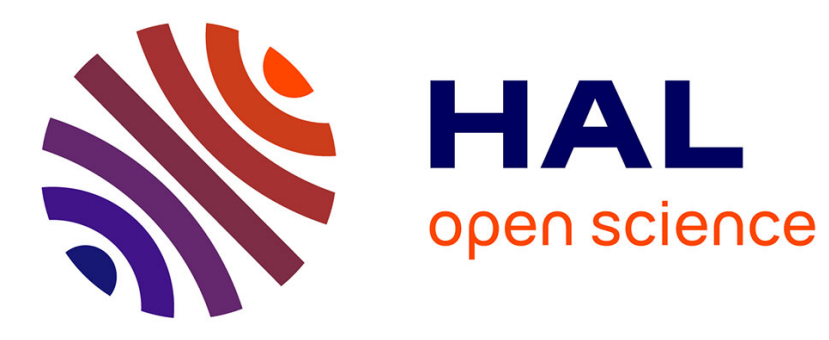

\title{
Soil contamination and human health: A major challenge for global soil security
}

Florence Carre, Julien Caudeville, Roseline Bonnard, Valérie Bert, Pierre Boucard, Martine Ramel

\section{> To cite this version:}

Florence Carre, Julien Caudeville, Roseline Bonnard, Valérie Bert, Pierre Boucard, et al.. Soil contamination and human health: A major challenge for global soil security. Global Soil Security Symposium, May 2015, College Station, United States. pp.275-295, 10.1007/978-3-319-43394-3_25 . ineris01864711

\section{HAL Id: ineris-01864711 \\ https://hal-ineris.archives-ouvertes.fr/ineris-01864711}

Submitted on 30 Aug 2018

HAL is a multi-disciplinary open access archive for the deposit and dissemination of scientific research documents, whether they are published or not. The documents may come from teaching and research institutions in France or abroad, or from public or private research centers.
L'archive ouverte pluridisciplinaire HAL, est destinée au dépôt et à la diffusion de documents scientifiques de niveau recherche, publiés ou non, émanant des établissements d'enseignement et de recherche français ou étrangers, des laboratoires publics ou privés. 


\title{
Human Health as another major challenge of Global Soil Security
}

Florence Carré, Julien Caudeville, Roseline Bonnard, Valérie Bert, Pierre Boucard, Martine Ramel

\begin{abstract}
This chapter aimed to demonstrate, by several illustrated examples, that Human Health should be considered as another major challenge of global soil security by emphasizing the fact that (a) soil contamination is a worldwide issue, estimations can be done based on local contamination but the extent and content of diffuse contamination is largely unknown; (b) although soil is able to store, filter and reduce contamination, it can also transform and make accessible soil contaminants and their metabolites, contributing then to human health impacts. The future scientific and societal challenges related to Soil-Human Health studies and soil security dimensions are discussed afterwards based on current programs and literature review.
\end{abstract}

F. Carré $\left(\Xi^{\circ}\right) \bullet$ J. Caudeville $\bullet$ R. Bonnard $\bullet$ V. Bert $\bullet$ P. Boucard $\bullet$ M. Ramel INERIS

Verneuil en Halatte, France

e-mail : florence.carre@ineris.fr 


\section{Chapter 10 \\ Human Health as another major challenge of Global Soil Security}

\subsection{Introduction}

Soil security refers to the maintenance and improvement of the world's soil resources so that they can continue to face six major challenges which are contributions to: (1) provision of food and fiber, (2) energy security, (3) water security, (4) climate change abatement, (5) biodiversity protection, (6) ecosystem service delivery (Koch et al., 2013; Koch et al., 2012). By being able to perform five functions, among them storing, filtering and transforming of nutrients, substances and water (CEC, 2006), soil largely contributes to the quality of air, food and water, which has a direct link to human health. This chapter aims to demonstrate that Human Health should be recognized as another major challenge of soil security. The focus is made on solid or liquid hazardous chemicals storage, filtration and transformation by soil, i.e. soil contamination. A state-of-the-art on worldwide soil contamination, the relations to human health and the emerging scientific and societal needs to identify and reduce soil contamination illustrate the demonstration.

\subsection{Soil contamination worldwide}

\subsubsection{Main soil contaminants}

Solid or liquid hazardous chemicals contaminants result mainly from industrial, agricultural land disposal, transport, urbanization, mining, irrigation and military processes (Jones et al., 2012, Panagos et al., 2013). In Europe, the United States and Australia, the main contaminants which have been reviewed so far are for about 60\% Heavy Metals and Total Petroleum Hydrocarbons (Huber and Prokop, 2012; Mulligan et al., 2001; State of the Environment Committee, 2011), then Polycyclic Aromatic Hydrocarbons (HAP), Benzene, Toluene, Ethylbenzene, and Xylene (BTEX), Chlorinated Hydrocarbons (CHC), cyanides and phenols (Panagos et al., 2013). These contaminants concern mainly sites operating under legislation which makes mandatory pollution monitoring and control, like the European Industrial Emission Directive 2010/75/EU1.

\subsubsection{Review of contaminated sites}

Two kinds of contamination are usually distinguished (Murphy and Hazelton, 2014):

- Local soil contamination occurs where intensive industrial activities, inadequate waste disposal, mining, military activities or accidents introduce excessive amounts of contaminants in soil;

\footnotetext{
${ }^{1} \mathrm{http} / / /$ ec.europa.eu/environment/industry/stationary/ied/legislation.htm
} 
- Diffuse soil contamination is the presence of a substance or agent in the soil as a result of human activity that caused it to be emitted from moving sources, from sources with a large area, or from many sources. Diffuse soil contamination occurs where emission, transformation and dilution of contamination in other media has occurred prior to their transfer to soil. Water and air actions can explain long-range transport of contaminants. As a result, the relationship between the contaminant source and the level and spatial extent of soil contamination is indistinct (Jones et al., 2012; Van Camp et al., 2004).

Panagos et al. (2013) estimated contaminated sites and potentially contaminated to be around 0.005 sites per capita for the European Union and a population of 1 billion. Based on these figures, Horta et al. (2015) estimated emerging economies to have 0.0025 contaminated sites and potentially contaminated per capita, their population being 2 billion, developing economies to have 0.001 contaminated sites and potentially contaminated per capita, their population being 4 billion. At global level, the estimates of contaminated sites and potentially contaminated are then between 10 million and 20 million sites (including uncertainties).

These figures, representing big numbers, concern mainly local contamination. Estimation of diffuse soil pollution could be done for instance by integrating available global monitoring data on hazardous chemicals, e.g the quantity of pesticides per ha of arable land for the period 20052009 (FAO, 2013) represented in Figure 10.1.

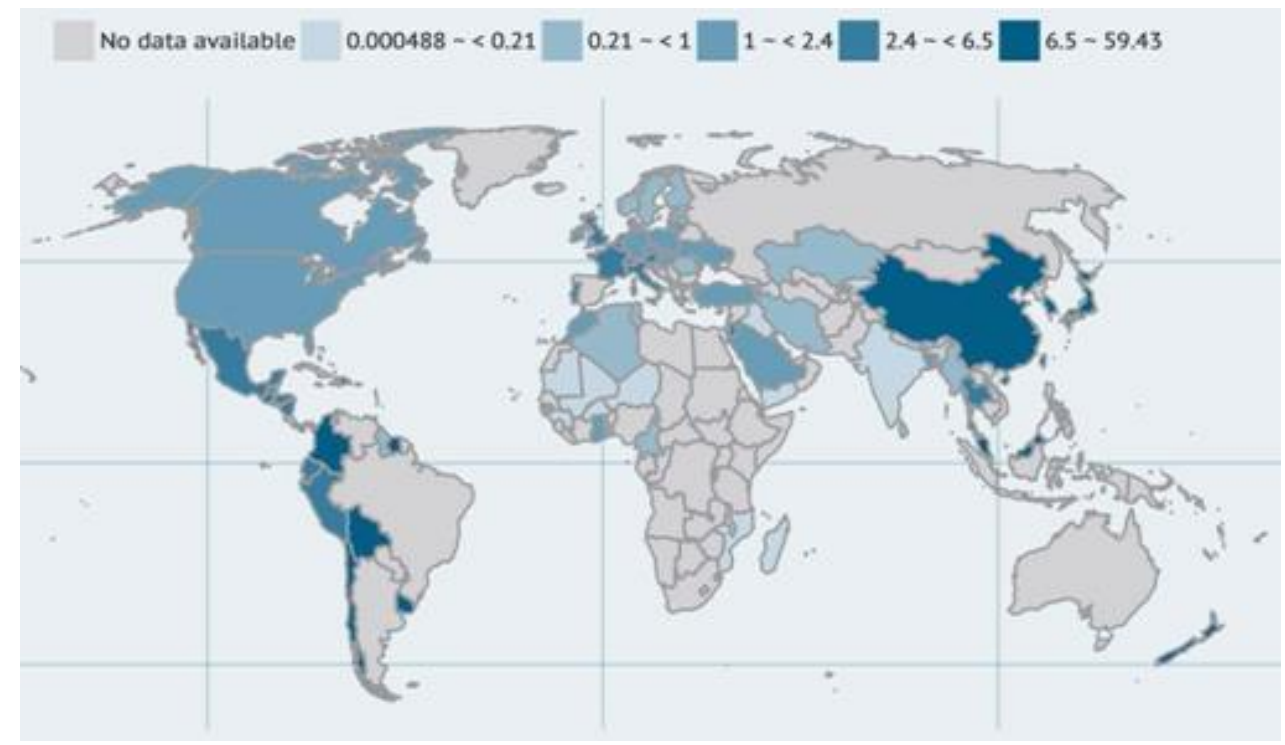

Figure 10.1 - Map of pesticides per ha of arable land (kg/ha- period 2005-2009) - Source: FAO (2013)

This map presents the distribution of only one category of hazardous chemicals, over the 350,000 inventoried and regulated substances ${ }^{2}$. It shows that, where data are available, $80 \%$ of pesticides are over-used, leading to diffuse soil contamination. This is actually the case for North, Central and South America, Western Europe, Middle East, China and New Zealand. What about the developing countries where data are currently missing? An extrapolation of the available data based on categories of economies would certainly show that $70 \%$ of the globe is over-

\footnotetext{
2 www.cas.org
} 
covered by pesticides. At this stage, more data on diffuse soil contamination are required at national level through systematic monitoring programs or food contamination controls.

As stated by Horta et al. (2015), remediation rates on identified contaminated sites are quite modest:

- European countries have undergone, only 5\% remediation (Panagos et al., 2013) of the identified and potentially contaminated sites and the number of recorded polluted sites across whereas the number of recorded contaminated site Europe is expected to increase by $50 \%$ by 2025 (EEAa, 2015);

- Australia proceeds to about $0.5 \%$ per annum of remediation (State of the Environment Committee, 2011) certainly about the same amount as the number of newly contaminated sites every year (Horta et al., 2015).

These small remediation numbers are explained by the high costs of remediation (see $\S 10.4 .4$ ) and lack of incentives for land valuation.

The next sections are describing the underlying processes of soil contaminants - human health relationships, the assessment procedure and some statistically-based cases.

\subsection{Soil contamination and human health}

The study of soils and human health is a complicated endeavor: traditional scientific approaches that isolate a single variable, such as a specific contaminant, and then investigate that variable are usually not effective, because many of the issues that affect human health involve complicated and synergistic relationships (Brevik and Sauer, 2015; Brevik and Burgess, 2013).

\subsubsection{General principles}

Soil contaminants can be exposed to humans by:

- transport processes like leaching, infiltration, run-off, gas volatilization, dispersion, advection, diffusion, sorption/desorption due to close connections to soil with air, water and biota.

- fate and transformation processes variable according to the types of contaminants: organic compounds can undergo hydrolysis, oxidation, biodegradation, sorption, while inorganic compounds undergo complexation, dissolution and /or changes in speciation (EPAa, 2013).

These processes depend on several factors that explain the bioaccessibility of the soil contaminants:

- inorganic compounds depend on climate and soil conditions like pH, cation exchange capacity also function of type and content of clay and type and content of organic matter, redox potential, Iron/Manganese oxides, soil moisture content, soil micro-organisms;

- Organic compounds depend mainly on their potential absorption in the food chain measured by their distribution coefficient (octanol/water), Henry constant, water solubility, half-life and bioconcentration factor (EPAa, 2013). A following section is dedicated specifically to persistent organic pollutants. 
The routes of exposure to humans are inhalation of dust and vapor coming from soil contaminants, ingestion of contaminated soil particles (mainly for children) or contaminated food, and dermal absorption through the skin. Once the intake by inhalation, ingestion or dermal contact have been done, the soil contaminant is absorbed by the gastrointestinal and pulmonary systems or absorbed by the skin and enters the systemic circulation system, representing the uptake and the bioavailable fraction (Murphy and Hazelton, 2014; EPAb, 2013; Dudka and Miller, 1999; Hawley, 1985).

When it exists, a soil guideline value (SGV) is a figure for the concentration of a contaminant in the soil that sets off 'possible risk' alarm bells. It means that further investigation and/or risk management are needed. These SGVs are generally derived from estimates of toxicity from a certain human intake of the soil rather than actual human uptake of the contaminant (Science Communication Unit, 2013). It is elaborated according to soil type, soil usage and the population type who can ingest or inhale the soil contaminant.

Regarding a contaminant, human health risk assessment is generally not framed only to soil contamination, but it involves also the contribution of other exposure media. Indeed, the estimation of human health risk is the combination of the hazard and the exposure of the contaminants from multiple pathways and routes usually identified from a site conceptual model. The ingested or inhaled dose is compared to the reference toxicological value (RTV) varying according to the exposure route, age, sex, genetic and health of populations (INERIS, 2009; Bonvallot and Dor, 2002). For a contaminant with threshold effects, a RTV means the dose or concentration below which the occurrence of an effect is not expected. For non-threshold effects, a TRV means the additional probability of occurrence of an effect to an exposure unit (INERIS, 2013).

Multimedia models (cf. example presented in Figure 10.2) which provide appropriate quantitative frameworks for evaluating the complex interactions between chemicals and the environment (Caudeville et al., 2012) can be used for assessing exposure.

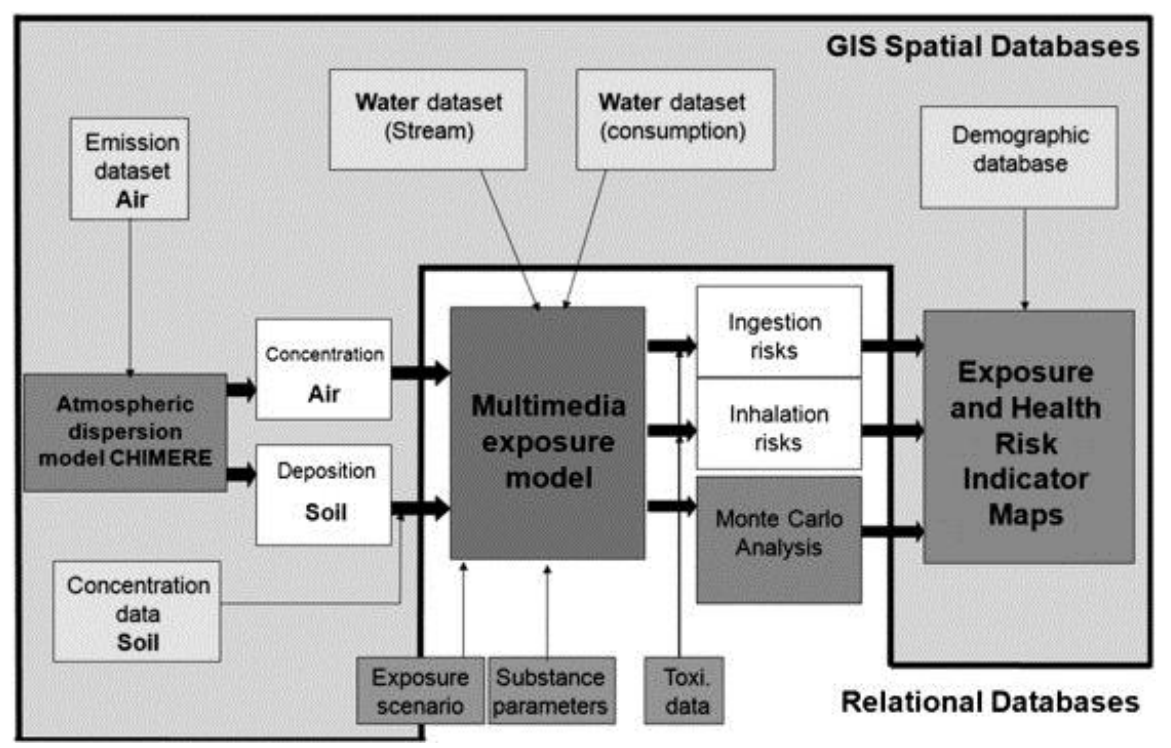

Figure 10.2- Block diagram of the transfer and exposure pathways taken into account in the PLAINE GIS-multimedia platform (source: Caudeville et al., 2012). 
These models can be spatialized (Caudeville et al., 2012; MacLeod et al., 2001; Feijtel et al., 1997), or not (Bonnard and McKone, 2010). They can also be integrated with PhysicologicallyBased Pharmaco-Kinetics models for assessing the uptake impact of a contaminant directly on a target tissue at individual levels (Maurau et al., 2011). The contribution of soil contaminants to the total exposure can be evaluated dividing the average inhalation or ingestion daily dose of soil contaminants by the total average daily dose of this contaminant (Caudeville et al., 2012).

When the risk is considered as unacceptable, remediation should be applied on the contaminated site in regards to its future usage.

\subsubsection{Focus on persistent organic pollutants}

Persistent organic pollutants (POPs) are extremely toxic substances for environment and human health at a world scale. They are persistent, bioaccumulative and toxic (PBT) chemicals and have long-range transport (Weber et al., 2008). In people, reproductive, developmental, behavioral, neurologic, endocrine, and immunologic adverse health effects have been linked to POPs. People are mainly exposed to POPs through contaminated food ingestion coming from contaminated soil and water. In people and other mammals alike, POPs can be transferred through the placenta and breast milk to developing offspring. A number of populations are at particular risk of POPs exposure, including people whose diets include large amounts of fish, shellfish, or wild foods that are high in fat and locally obtained. In addition, sensitive populations, such as children, the elderly, and those with suppressed immune systems, are typically more susceptible to many kinds of pollutants, including POPs. Because POPs have been linked to reproductive impairments, men and women of child-bearing age may also be at risk (EPA, 2015).

Since 1995 the international community has been working on implementing the Stockholm Convention $^{3}$ measures to eliminate or reduce the release of POPs into the environment. This Convention entered into force in May 2004. Initial action has been taken towards twelve POPs: Aldrin, Chlordane, DDT, Dieldrin, Endrin, Heptachlor, Hexachlorobenzene, Mirex, Toxaphene, PCBs, PCDDs and PCDFs. In 2009, extension has been done to 9 substances: Alpha Hexabromocyclododecane, Beta hexachlorocyclohexane, Chlordecone, Hexabromobiphenyl, Hexabromodiphenyl ether and heptabromodiphenyl ether (commercial octabromodiphenyl ether), Lindane, Pentachlorobenzene, Perfluorooctane sulfonic acid, its salts and perfluorooctane sulfonyl fluoride, Technical endosulfan and its related isomers, Tetrabromodiphenyl ether and pentabromodiphenyl ether (commercial pentabromodiphenyl ether). Endosulfan and Hexabromocyclododecane were added to the list in resp. 2011 and 2013. These 23 POPs are either pesticides, either industrial chemicals or by-products unintentionally produced during most forms of combustion. All of them can then be found in soils.

Emissions of these substances are regularly monitored in Europe, as shown in Figure 10.3 (source: EEAb, 2015).

\footnotetext{
${ }^{3} \mathrm{http}: / /$ www.pops.int/documents/convtext/convtext_en.pdf
} 


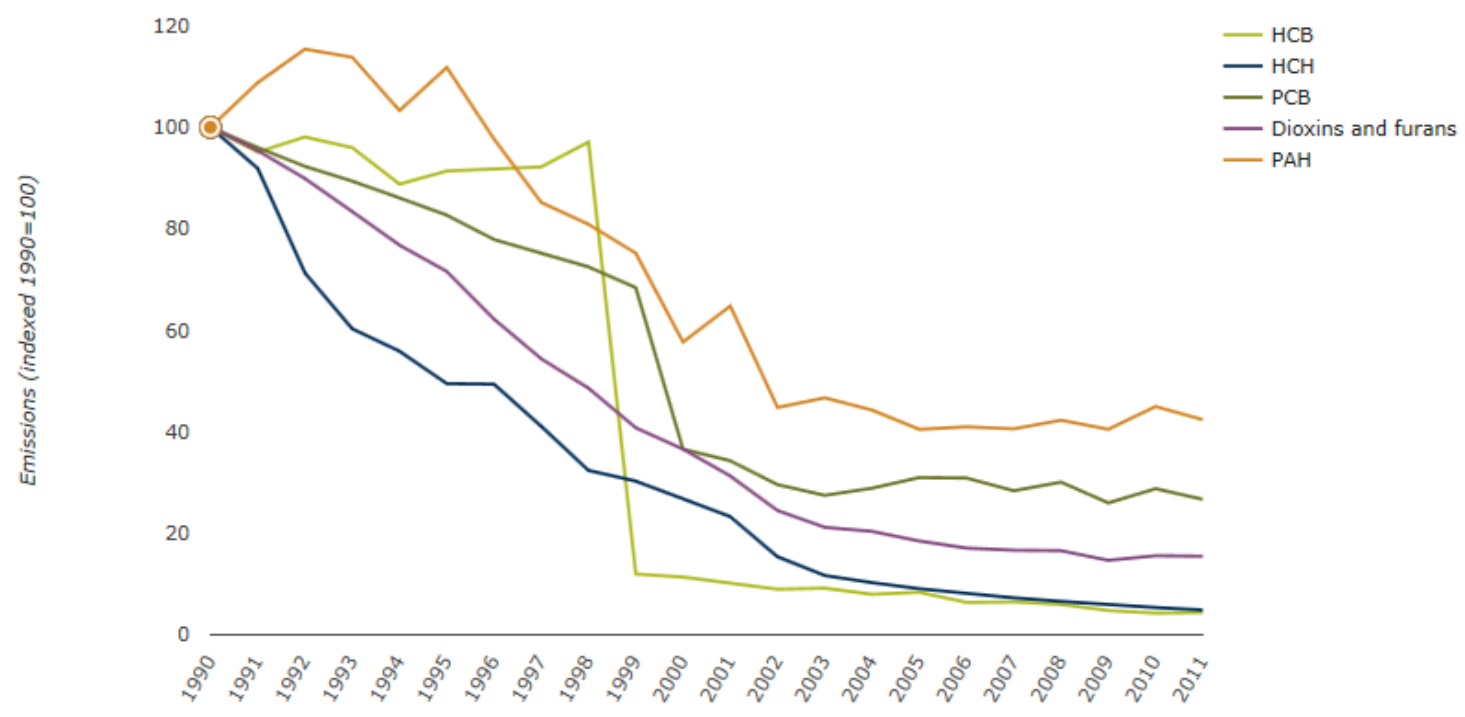

Figure 10.3- Emission trends of POPs from 1990 to 2011 (EEAb, 2015) - HCB - hexachlorobenzene, HCH - hexachlorocyclohexane, PCBs - polychlorinated biphenyls; dioxins \& furans; and PAHs polyaromatic hydrocarbons.

The vast majority of the 33 countries members of the European Environmental Agency have decreased their emissions due to the reduction of industrial, commercial and household uses. But as explained previously, these substances remain in undisturbed soils for long time-period and can be transferred to other locations once the soils are disturbed. Soil monitoring is then useful to complement the emission monitoring. In Europe, two attempts were done for soil mapping of POP. Villanneau et al. (2011) mapped some POPs in the North of France and demonstrated that it is possible to discriminate soils with POPs spatially correlated from others more randomly distributed perhaps due to redeposition phenomena. Ballabio et al. (2013) showed that PCB concentrations of Northern Italy, in mountainous areas, are highly correlated with soil temperature and organic carbon content, meaning that PCB concentrations follow weather seasonality.

Because POP measurements and analysis can be very expensive, mapping the soil POP burden can be facilitated through environmental bio-indicators such as lichens and mosses as indicator of air pollution (Augusto et al., 2013). Research on soil POP pollution bio-indicator is now at the initial stage. The increase of knowledge on soil microbial activity with the development of new tools could certainly lead to better identify and assess soil POP bio-indicators.

\subsubsection{Some potential and statistically-based cases of health effects of soil contamination}

\subsubsection{Potential health effects of soil contaminants}

WHO listed some soil contaminants having potential effects of human health. This list has been completed by Brevik and Burgess (2013). It is presented below.

Table 10.2- WHO chemicals of major public health concern directly in relation to soils and human health impacts. Sources: Science Communication Unit (2013), Brevik \& Burgess (2013), US Agency for Toxic Substances \& Disease Registry (website): www.atsdr.cdc.gov 


\begin{tabular}{|c|c|c|}
\hline $\begin{array}{c}\text { Chemical of concern, } \\
\text { Sources/uses }\end{array}$ & Toxic to humans how? & Health effects \\
\hline $\begin{array}{l}\text { Cadmium } \\
\text { Zinc smelting, mine } \\
\text { tailings, burning coal or } \\
\text { garbage containing } \\
\text { cadmium, rechargeable } \\
\text { batteries (nickel- } \\
\text { cadmium batteries } \\
\text { account for over four- } \\
\text { fifths of cadmium } \\
\text { consumption), pigments, } \\
\text { TVs, solar cells, steel, } \\
\text { phosphate fertiliser, } \\
\text { metal plating, water } \\
\text { pipes, sewage sludge. }\end{array}$ & $\begin{array}{l}\text { Cadmium in soil or water } \\
\text { used for irrigation can lead } \\
\text { to accumulation in plants } \\
\text { that enter the human food } \\
\text { chain. Cadmium may also } \\
\text { accumulate in animals at } \\
\text { levels that do not affect the } \\
\text { animal's health, but can } \\
\text { affect humans consuming } \\
\text { animal products. }\end{array}$ & $\begin{array}{l}\text { Liver and kidney damage, low } \\
\text { bone density. } \\
\text { These symptoms are known as } \\
\text { itai-itai disease. First identified } \\
\text { when cadmium from mining in } \\
\text { the Toyoma Prefecture of Japan } \\
\text { led to high levels of cadmium in } \\
\text { rice, which accumulated in local } \\
\text { people. Diets poor in iron and } \\
\text { zinc vastly increase the negative } \\
\text { health effects of cadmium. } \\
\text { Carcinogenic (by inhalation). }\end{array}$ \\
\hline $\begin{array}{l}\text { Dioxin } \\
\text { Including Polychlorinated } \\
\text { dibenzodioxins (PCDD) } \\
\text { and Polychlorinated } \\
\text { dibenzofurans (PCDF). } \\
\text { Waste incineration, } \\
\text { reprocessing metal } \\
\text { industry, paper and pulp } \\
\text { industry, contaminated } \\
\text { herbicides (a major } \\
\text { source). Stored PCB- } \\
\text { based industrial waste } \\
\text { oils (often with large } \\
\text { amounts of PCDFs). }\end{array}$ & $\begin{array}{l}\text { Human exposure to dioxin } \\
\text { and dioxin-like substances } \\
\text { occurs mainly through } \\
\text { consumption of } \\
\text { contaminated food. More } \\
\text { than } 90 \% \text { of human } \\
\text { exposure is through food, } \\
\text { mainly meat and dairy } \\
\text { products, fish and shellfish. }\end{array}$ & $\begin{array}{l}\text { Dioxins are highly toxic and can } \\
\text { cause reproductive and } \\
\text { developmental problems, damage } \\
\text { the immune system, interfere } \\
\text { with hormones and also cause } \\
\text { cancer. }\end{array}$ \\
\hline $\begin{array}{l}\text { Lead } \\
\text { Batteries, solder, } \\
\text { ammunition, pigments, } \\
\text { paint, ceramic glaze, hair } \\
\text { colour, fishing } \\
\text { equipment, leaded } \\
\text { gasoline (vehicle } \\
\text { exhausts), mining, } \\
\text { plumbing, coal burning, } \\
\text { water pipes }\end{array}$ & $\begin{array}{l}\text { Leaded fuel and mining } \\
\text { activities are common causes } \\
\text { for elevated lead levels in } \\
\text { topsoil. }\end{array}$ & $\begin{array}{l}\cdot \text { Neurological damage } \\
\cdot \text { Lowers IQ and attention } \\
\cdot \text { Hand-eye co-ordination } \\
\text { impaired } \\
\cdot \text { Encephalopathy } \\
\cdot \text { Bone deterioration } \\
\cdot \text { Hypertension } \\
\cdot \text { Kidney disease }\end{array}$ \\
\hline $\begin{array}{l}\text { Mercury } \\
\text { Electrical switches, } \\
\text { fluorescent light bulbs, } \\
\text { lamps, batteries, } \\
\text { thermometers, dental } \\
\text { fillings, mining }\end{array}$ & $\begin{array}{l}\text { Main exposure route for the } \\
\text { population at large is via } \\
\text { eating contaminated seafood. } \\
\text { For children is direct } \\
\text { ingestion of soil. }\end{array}$ & $\begin{array}{l}\cdot \text { Central nervous system (CNS) } \\
\text { and gastric system damage } \\
\cdot \text { Affects brain development, } \\
\text { resulting in a lower IQ } \\
\cdot \text { Affects co-ordination, eyesight }\end{array}$ \\
\hline
\end{tabular}




\begin{tabular}{|l|l|l|}
\hline $\begin{array}{l}\text { (particularly } \\
\text { artisanal/small scale gold } \\
\text { mining), pesticides, } \\
\text { medical waste, burning } \\
\text { coal and fuel oil, chlor- } \\
\text { alkali industry. }\end{array}$ & $\begin{array}{l}\text { and sense of touch } \\
\text { - Liver, heart and kidney damage. } \\
\text { - Teratogenic }\end{array}$ \\
\hline $\begin{array}{l}\text { Herbicides derived } \\
\text { from trinitrotoluene } \\
\text { may have the impurity } \\
\text { dioxin, which is highly } \\
\text { toxic. Synthetic } \\
\text { insecticides, such as DDT } \\
\text { (now banned) can still be } \\
\text { found in the environment } \\
\text { worldwide. }\end{array}$ & $\begin{array}{l}\text { Organic pesticides } \\
\text { accumulate in the food chain. }\end{array}$ & $\begin{array}{l}\text { Organic chemicals, including } \\
\text { pesticides, have been linked to a } \\
\text { wide range of health problems, } \\
\text { but humans tend to be exposed to } \\
\text { a cocktail of these chemicals at } \\
\text { low levels. Conclusive proof of } \\
\text { cause and effect in humans is } \\
\text { challenging. }\end{array}$ \\
\hline
\end{tabular}

Main of the soil contaminants are indirectly ingested via the food chain.

\subsubsection{Some statistically-based health effects of soil contaminants}

- Death Triangle of soil dioxins and heavy metal pollution (Italy).

Hazardous-waste sites in the Campania region of Italy differ in that they are distributed over a wide densely populated area, with an estimated 1230 illegal dump sites in what has been referred to as "The Triangle of Death" (Martuzzi et al., 2009). This is because, since the 1980s, hazardous-waste dumping has gone on largely uncontrolled. In addition to voluminous amounts of household waste, the region has also been plagued by widespread illegal dumping of toxic industrial chemicals and low-level radioactive wastes. The situation has been aggravated by the ongoing practice of burning rubbish, which in turn creates dioxins and other toxic compounds (PAH, heavy metals). De Felice et al. (2012) have demonstrated that the soil pollution in this region is significantly associated with effects on exposed population like higher oxidative stress, shorter telomere length and lower telomerase activity. These are known determinants of cell senescence and aging-related meiotic dysfunction in women, in peripheral blood mononuclear cells from healthy pregnant women, subjected to therapeutic abortion in the second trimester of pregnancy.

- Soil organochlorine chemicals around Besançon (France):

Viel et al. (2011) worked on a study area of three electoral wards (170,000 inhabitants), containing or surrounding the municipal solid waste incinerators (MSWI) of Besançon City (Eastern France). The MSWI of Besançon was put into service in 1971. Some legal guidelines for incinerator emissions have not been followed at this location. For example, in 1997, exhaust gases were not maintained at sufficient temperatures, allowing dioxins to be emitted. The first time that the dioxin concentration of an exhaust gas was ever measured (December 1997), it was found to be $16.3 \mathrm{ng}$ WHO1998-toxic equivalency factor (TEQ) $/ \mathrm{m}^{3}$, whereas the European guide value is $0.1 \mathrm{ng}$ WHO1998-TEQ $/ \mathrm{m}^{3}$. Once emitted the dioxins and its congeners (organochlorines), they are deposed in topsoil in very short-time where they accumulate. Exposure pathway of organochlorines is mainly through ingestion of contaminated food (above 
all animal lipids from meat, poultry and eggs, fish, shellfish, and dairy products like cheese and milk). Viel et al. worked on epidemiology around the site and collected serum samples from people having declared non-Hodgkin lymphoma and from people having not declared any pathologies. They found correlations between serum organochlorine concentrations and nonHodgkin lymphoma.

- Links between $\mathrm{Cd}$ and $\mathrm{Pb}$ soil pollution with nephrotoxicity in Mbeubeuss (Senegal):

Cabral et al. (2015) studied the links between the population located nearby the discharge of Mbeubeuss (30 km from Dakar City centre) where more than 395,000 tons per year of household solid waste have been received since 1970 with highly lead and Cadmium concentrated soils and nephrotoxicity. Blood and urine concentrations were measured for subjects living on control (less exposure to lead and cadmium) and exposed sites for more than 5 years. They found that exposed subjects exhibited significantly higher $\mathrm{Cd}$ and $\mathrm{Pb}$ levels in blood and urine than the controls. It has already been reported that one of the major mechanisms of the toxicity of both these metals was certainly driven by induction of oxidative stress conditions due to the overproduction of reactive oxygen species. As a result of this excessive production of reactive oxygen species in exposed subjects, a disturbance of the antioxidant defense system as well as an occurrence of lipid peroxidation were evidenced. Furthermore, changes in several sensitive and specific markers of nephrotoxicity clearly suggested the occurrence of early signs of impaired renal function for the discharge neighboring population. Regarding to these results, reactive oxygen species generation following low to moderate environmental exposure to $\mathrm{Pb}$ or $\mathrm{Cd}$ could be a possible mechanism of genotoxicity.

Regarding the contribution of soil contamination to population diseases, these case studies should be considered with caution since, as already explained previously, exposure and human health risk assessment are case by case approaches. In a widespread goal, more data on the contribution of other media, on the population, the time and duration of exposure (genetics, behavior,...) and on the presence of other kinds of contaminants (types and concentrations) would be needed (see the exposome concept developed in §12.4.3).

\subsection{Future scientific and societal challenges related to studies on Soil - Human health relations}

This section is based on the dimensions of soil security which has been described by McBratney et al. (2014). These dimensions are discussed in relation to the soil contamination topics.

\subsubsection{Increasing the knowledge on soil condition}

Soil condition is the current state of the soil, including modification by human activities McBratney et al. (2014). In our case, the focus is made on soil contaminants. 


\subsubsection{Emerging contaminants: the unknowns of soil condition}

The NORMAN 4 European network of reference laboratories, research centres and related organisations for monitoring of emerging environmental substances, is providing definitions of emerging substances and emerging pollutants from the monitoring point of view:

- "Emerging substances" can be defined as substances that have been detected in the environment, but which are currently not included in routine monitoring programmes at EU level and whose fate, behaviour and (eco)toxicological effects are not well understood.

- "Emerging pollutants" can be defined as pollutants that are currently not included in routine monitoring programmes at the European level and which may be candidates for future regulation, depending on research on their (eco)toxicity, potential health effects and public perception and on monitoring data regarding their occurrence in the various environmental compartments.

Sauvé and Desrosiers (2014) gave a broader definition of emerging contaminants preferably termed "contaminants of emerging concern (CEC)", defined as naturally occurring, manufactured or manmade chemicals or materials which have now been discovered or are suspected present in various environmental compartments and whose toxicity or persistence are likely to significantly alter the metabolism of a living being.

In April 2015, the NORMAN network identified a preliminary list of the 969 currently most frequently discussed emerging substances and pollutants (NORMAN, 2015) in aquatic systems. Due to subsurface water movements or anthropogenic activities like application of sewage sludge (INERIS, 2014), not all but main of these identified substances and pollutants can be found in soils. Some emerging contaminants are Persistent Organic Pollutants (see §10.3.2), Pharmaceuticals and personal care products (PPCPs), i.e. any product used by individuals for personal health or cosmetic reasons or used by agribusiness to enhance growth or health of livestock, Endocrine-Disrupting Chemicals (EDCs), including synthetic estrogens and androgens, naturally occurring estrogens, and other chemicals that affect at low-dose hormonal functions in aquatic and terrestrial organisms.

The main challenges related to contaminants of emerging concern will be, in the coming years, to better understand their concentrations in the environment [through very robust detection and analytical methods] as well as their toxic effects on organisms. Better management of risks to human health and the environment (Sauvé and Desrosiers, 2014) should be done by prioritizing contaminants to include to existing regulations (e.g. the European Water Framework Directive, REACH Directive, Ground Water Directive, Waste Directive) for usage and production restriction at domestic and industrial levels, based inter alia on (eco)toxicological criteria.

\subsubsection{Development of new tools for a better assessment of soil condition}

Soil monitoring of contaminants (including those of emerging concern) would be too expensive to be achieved systematically. In addition to the collection of legacy data on historical uses of sites, one of the solutions would be, to intensify the coupling between soil biomonitoring and

\footnotetext{
${ }^{4}$ http://www.norman-network.net/?q=node/19
} 
analytical tools and methods, where health effects are observed on soil fauna and flora. This can be done for instance with Effect Directed Analysis which aims to identify the compounds causing these effects after reducing sample complexity by combining biotests with fractionations (Fetter et al., 2014). More generally, further (eco)toxicological research would be necessary to better assess human health risk particularly on chemical forms of contaminants and their toxicity related to environmental and biological conditions. Research devoted to a better understanding of the soil/water/air/flora nexus and the contaminants behavior under climate change conditions, of endocrine disruptors low-dose (eco)toxicological effects and of soil contaminants mixture (eco)toxicological effects would be very useful in the future.

Once a site is considered as contaminated, it is necessary to provide enough accurate data to minimize lack of statistical representativeness and increase the spatial quantification. The time spent for evaluating the presence and extent of contamination can be reduced by an adequate sampling plan (Malherbe, 2002) which can at the same time, reduce the project costs (Horta et al., 2015). Proximal sensing that is all methods that sense the soil from outside (McBratney et al., 2011; Viscarra Rossel et al., 2011) can help in supporting the identification and characterization of contaminated site particularly with conjoint use of Vis-NIR and Portable X-ray fluorescence proximal sensors and laboratory analysis (Horta et al. 2015). Extending innovation on these proximal sensors would be then of great interest for characterizing soil contamination.

\subsubsection{Development of new remediation techniques for improving the soil condition}

Remediation is considered as the management of the contaminant at a site so as to prevent, minimize or mitigate damage to human health, property or the environment. Two distinct classes of soil remediation can be defined: (a) in situ, (b) ex-situ (with on-site and off-site interventions). In-situ remediation - meaning that no excavation of the contaminated soil occurs - is often preferred because it is generally less expensive. However, it generally takes a longer time to effect treatment to the desired limits and there is less certainty about the uniformity of treatment because of the inherent variability in soil and aquifer characteristics and difficulty in monitoring progress. On the other hand, excavating a contaminated area (ex-situ approach) and treating the material on the same site (ex-situ, on-site) or transporting it to a remote site for cleaning (ex-situ, off-site) can often be more complicated and expensive. Nevertheless, ex-situ off-site remediation has the added bonus of taking the bulk of contaminants away before they can spread further. It also allows homogenization of the contaminated soil before treatment and ensures monitoring so that soils are cleaned to the desired limits within a relatively short time [suitable with transaction time of attractive land as high value commercial and residential lands] (Lodolo, 2015). Ex-situ remediation with soil excavation and disposal to landfill "dig and dump" currently represents one third of the remediation technologies in Europe (Panagos et al., 2013). However, since space is needed for ex-situ remediation and particularly for disposal to landfill, it enhances soil grabbing which is not compatible with the UNCCD "zero-net land degradation" Sustainable Development Goal for Rio $+20^{5}$. More in situ remediation should then be expected in the future. The related techniques are: .pdf 
- Thermal processes which use heat to increase the volatility, to burn, decompose, destroy or melt the contaminants. Cleaning soil with thermal methods may take only a few months or several years. The time it takes depends on type and amounts of chemicals present, size and depth of the polluted area, type of soil and conditions present;

- Physico-chemical treatments which use the physical and/or chemical and/or electrical properties of the contaminants or of the contaminated medium to destroy (i.e., chemically convert), separate, or contain the contamination. The technologies are also sensitive to certain soil parameters which influence the contaminant availability and extractability such as the presence of clay or humic materials, $\mathrm{pH}$, soil moisture;

- Biological treatment which is a process whereby soil contaminants are transformed or degraded into innocuous substances such as carbon dioxide, water, fatty acids and biomass, through the action of microbial metabolism. Biological processes are typically implemented at low cost. Contaminants can be destroyed and often little to no residual treatment is required. However, the process requires more time and it is difficult, in general, to determine whether contaminants have been completely destroyed. Additionally, microbes may often be sensitive to toxins or highly concentrated contaminants in the soil (Lodolo, 2015).

Biological treatments and more specifically the Gentle Remediation Options (GRO), which include in situ contaminant stabilization ("inaction") and plant-based remediation (or phytoremediation), allow for enhancing ecosystem services by contributing to the restoration of soil functions. A lot of efforts have been done for the last ten years to increase the efficiency of Trace Element remediation by testing different soil management practices, different crops under different soil conditions (Kidd et al., 2015). Further research and development are needed for remediating other kinds of contaminants and for increasing the knowledge on bioaugmentation techniques in order to improve the efficiency of these positive environmental balance technologies.

Regarding broad aspects of soil remediation, it is important to evaluate the effects of exhaustive remediation alternatives on soil functions when assessing the overall sustainability of decision options. To this aim, a generic approach conceptualizing linkages between soil functions, soil ecosystem services and the environmental, social and economic sustainability domains has been proposed by Rosén et al. (2015) through the development of the SCORE tool based on multicriteria decision analysis. This tool integrates also a quantification of the uncertainties and their impact on decision-making. This approach is revolutionizing the remediation approaches by combining experts and stakeholders' judgments and preferences -which deals with the integration of the connectivity dimension (cf §12.4.3)- and by integrating sustainable land management concepts -which deals with the integration of soil condition and capability dimensions- in the current risk-based approaches.

\subsubsection{Increasing the connectivity and the codification related to soil contamination}

Connectivity is the social connection of soil managers, custodians, and users of soil products and services to the soil and to each other whereas codification relates to policy frameworks, it is the identification of policies that degrade soil security and those that secure soil (McBratney et al., 2014). These two dimensions are discussed together in this section because awareness raising 
of the broad society allows for enhancing best practices that can sometimes lead to either new policies either new standards, labels or voluntary certificates. Since connectivity is considered here as the driver of codification, this section is dedicated to connectivity.

As already emphasized by Bouma (2015), one of the success keys for securing soil is the involvement of the society [and all concerned stakeholders] in the preparatory and implementation phases of a soil management project. The concerned stakeholders are those involved in field scale and regional scale spatial planning. The potential actors are policy / decision makers, private and/or public funders and citizens who live in the area and the surrounding area concerned by the project. The identification of the societal needs at the initial stages of the project, facilitated by knowledge brokers, increases the acceptability of the project and its sustainability. During the implementation phase, the societal involvement allows also for a better understanding of technical bottlenecks that could lead to deviations of the project target. Such trans-disciplinary research project eases the integration of research outcomes in decision making and policies.

Another success key raised by Bouma (2015) is the development of inter and trans-disciplinary programs dealing with food, water, climate, biodiversity and energy problems. Health is also an important topic to target for which, as demonstrated previously, soil has a central place. Monitoring soil, water, fauna/flora and human health through common programs would lead to a better understanding of the critical zone and would participate to the increase of knowledge on the exposome concept. The exposome is the measure of all the exposures of an individual in a lifetime and how those exposures relate to health ${ }^{6}$. On a long-term, this knowledge will lead to a better prevention of pollution and a better land management through policies, standards or individual and societal voluntary basis actions.

\subsubsection{Increasing the knowledge on soil capital}

The dimension of soil capital is underpinned by the notion that by placing a monetary value on an asset enables a society to value or secure the asset and make meaningful comparisons of soil with different capabilities and conditions (McBratney et al., 2013).

Evaluating the cost of soil contamination at global level allows for emphasizing the importance of protecting soil against contamination. The cost can be evaluated according to four components as described in Gorläch et al. (2004):

- The on-site or private cost (PC) of damage which is for instance the costs of the reclamation of the site within redevelopment project performed by private investor. It is also the cost of impact monitoring;

- The on-site private cost of mitigation and repair measures (MC) which is the cost of e.g. demolition of contaminated buildings, soil decontamination and treatment, acquisition of contaminated land and refitting of forests;

- The off-site (social) cost (SC) which is the cost of human and environmental impacts (e.g. cost of disease, loss of agricultural income, decrease of housing prices)

- The non-user cost (DC) which is the cost of loss of non-use value for citizens.

${ }^{6} \mathrm{http}: / /$ www.cdc.gov/niosh/topics/exposome/ 
This cost varies according to the type of contaminant, the spatial extent of the pollution and its intensity, the natural characteristics of the contaminated site, the socio-economic characteristics of the surrounding area and the tolerable risk levels depending on the regulation of each country. Based on literature review of Horta et al. (2015) which estimate the total number of locally contaminated sites to about 10 and 20 Millions, and evaluation of costs made by Gorläch et al. (2004) and Panagos et al. (2013) which provided data representative of the European continent (so easily upscalable to other continents) rough estimations can be made of the total cost of soil contamination (Table 10.3).

Table 10.3 - Estimation of the total cost of soil contamination based on data representative of the European continent (Panagos et al., 2013; Görlach et al., 2004) and rules of three.

\begin{tabular}{|c|c|c|c|c|c|c|}
\hline \multirow{2}{*}{$\begin{array}{c}\text { Number of } \\
\text { sites (total } \\
\text { estimation } \\
\text { in bold) }\end{array}$} & \multicolumn{6}{|c|}{ Cost (in $M € / y r$ ) } \\
\hline & $\begin{array}{l}\text { PC } \\
\text { (\%total } \\
\text { cost) }\end{array}$ & $\begin{array}{l}\text { MC } \\
\text { (\%total } \\
\text { cost) }\end{array}$ & $\begin{array}{l}\text { SC } \\
\text { (\%total } \\
\text { cost) }\end{array}$ & $\begin{array}{l}\text { DC } \\
\text { (\%tota } \\
\text { l cost) }\end{array}$ & $\begin{array}{l}\text { Total cost } \\
(\mathrm{PC}+\mathrm{MC}+\mathrm{SC} \\
+\mathrm{DC})\end{array}$ & $\begin{array}{l}\text { Study extent } \\
\text { (authorship) }\end{array}$ \\
\hline $\begin{array}{l}1.5 \mathrm{M} \\
10-20 \mathrm{M}\end{array}$ & $\begin{array}{l}192 \\
(0.7)\end{array}$ & $\begin{array}{l}6,658 \\
(26.7)\end{array}$ & $\begin{array}{l}17,126 \\
(68.7)\end{array}$ & $\begin{array}{l}965 \\
(3.9)\end{array}$ & $\begin{array}{l}24,941 \\
166,273=- \\
332,546\end{array}$ & $\begin{array}{l}\text { European extent - } \\
\text { intermediate } \\
\text { costs estimated } \\
\text { from different } \\
\text { case studies } \\
\text { (Görlach et al., } \\
2004)\end{array}$ \\
\hline $\begin{array}{l}342,000 \\
\mathbf{1 0 - 2 0 M}\end{array}$ & 171 & 6,500 & 16,725 & 949 & $\begin{array}{l}24,345 \\
\mathbf{7 1 1 , 8 4 2} \\
\mathbf{1 , 4 2 3 , 6 8 4}\end{array}$ & $\begin{array}{l}\text { European extent- } \\
\text { Management Cost } \\
\text { has been } \\
\text { estimated based } \\
\text { on survey } \\
\text { (Panagos et al., } \\
2013 \text { ) and other } \\
\text { types of costs } \\
\text { have been } \\
\text { estimated based } \\
\text { on the \%total cost } \\
\text { of Görlach et al. } \\
\text { (2004) }\end{array}$ \\
\hline
\end{tabular}


This table provides an estimation of the global cost of local contamination that is between 166 billion $€$ (185 billion US \$)/ yr and 1.4 trillion $€$ (1.11 trillion US \$)/ yr (between 0.25 and 1.89\% of global GDP). This upper boundary represents $10 \%$ of the maximum cost of climate change estimated by Stern (2006) which is about $20 \%$ of the global GDP. This wide range cost estimation emphasizes the fact that many environmental and social drivers influence the total costs. Rough estimates of the cost are then associated with many uncertainties that would decrease when assessing the cost at field or regional scales.

These high number estimates, which show that soil contamination is a highly relevant economic issue, are based only on local contamination data, not on diffuse contamination.

Furthermore, in a context of bringing value to contaminated sites, these numbers should be analyzed in regards to the economic valuation of ecosystem services enhanced by soil restoration. Such evaluation could enhance a dynamic and smart green businesses related to the remediation market.

\subsection{Conclusions}

This chapter aimed to demonstrate that Human Health should be considered as another major challenge of global soil security by emphasizing the fact that:

(a) Soil contamination is a worldwide issue. Estimations can be done based on local contamination but the extent and content of diffuse contamination is largely unknown.

(b) Although soil is able to store, filter and reduce contamination, it can also transform and make accessible soil contaminants and their metabolites, contributing then to human health impacts. This has been illustrated by several examples.

The future scientific and societal challenges related to Soil-Human Health studies and soil security dimensions are:

(a) For the condition and capability dimensions: more focus on emerging contaminants, more fast analytical tools and remediation techniques dealing with sustainable land management;

(b) For the connectivity and codification: more transdisciplinary approaches, multi-actors involvement and multi-disciplinary Environment-Health monitoring programs;

(c) For the capital dimension: better assessment of contamination costs but also economic value of remediation options.

\section{References}

Augusto S., Máguas C., Branquinho C. (2013). Guidelines for biomonitoring persistent organic pollutants (POPs), using lichens and aquatic mosses - A review. Environmental Pollution (180):330-338. 
Ballabio C., Guazzoni N., Comolli R., Tremolada P. (2013). Highly spatially- and seasonallyresolved predictive contamination maps for persistent organic pollutants: Development and validation. Science of The Total Environment (458-460): 546-554.

Bonnard R., McKone T.E. (2010). Integration of the predictions of two models with dose measurements in a case study of children exposed to the emissions of a lead smelter.

Hum Ecol Risk Assess 15(6):1203-26.

Bonvallot N., Dor F. (2002). Valeurs toxicologiques de référence : méthodes d'élaboration . Rapport InvS. http://www.sante.gouv.fr/IMG/pdf/Les valeurs toxicologiques de reference methodes d elab oration.pdf. Accessed 10 Sep 2015.

Bouma J. (2015): Reaching out from the soil-box in pursuit of soil security, Soil Science and Plant Nutrition, DOI: 10.1080/00380768.2015.1045403

Brevik, E.C., Burgess, L.C. eds (2013) Soils and Human Health.Boca Raton: CRC Press.

Brevik E.C., Sauer T.J., 2015. The past, present, and future of soils and human health studies. Soil (1) : 35-46.

Cabral M., Toure A., Garçon G., Diop C., Bouhsina S. , Dewaele D., Cazier F., Courcot D., Tall-Dia A., Shirali P., Diouf A., Fall M., Verdin A., 2015. Effects of environmental cadmium and lead exposure on adults neighboring a discharge: Evidences of adverse health effects. Environmental Pollution Volume (206) : 247-255.

Caudeville J., Bonnard R., Boudet C., Denys S., Govaert G., Cicolella A. (2013). Development of a spatial stochastic multimedia exposure model to assess population exposure at a regional scale. Science of the Total Environment (432) : 297-308.

CEC (Commission of the European Communities) (2006). Communication from the Commission to the Council, the European Parliament, the European Economic and Social Committee and the Committee of the Regions - Thematic Strategy for Soil protection, Commission of the European Communities. COM, Brussels, p.231.

De Felice B., Nappi C., Zizolfi B., Guida M., Di Spiezio Sardo A., Bifulco G., Guida M. (2012). Telomere shortening in women resident close to waste landfill sites. Gene 500 (1): 101-106.

Dudka S, Miller WP (1999). Permissible concentrations of arsenic and lead in soils based on risk assessment. Water Air Soil Pollution (113):127-32.

EEAa, 2015. Progress in management of contaminated sites. http://www.eea.europa.eu/downloads/3317ce15ea77ed41a9753f4781b1dcca/1441389594/p rogress-in-management-of-contaminated-1.pdf?direct=1. Accessed 31 Aug 2015. 
EEAb, 2015. Persistent organic pollutant emissions. http://www.eea.europa.eu/data-andmaps/indicators/eea32-persistent-organic-pollutant-pop-emissions-1/assessment-4. Accessed 12 Sep 2015.

EPAa, 2013. Fate and Transport, Risk Assessment Training and Experience, Exposure Assemment Course Series - EXA 404. http://www.epa.gov/risk/expobox/tutorials.htm. Accessed 30 Mar 2015.

EPAb, 2013. General Concepts of Exposure, Risk Assessment Training and Experience, Exposure Assemment Course Series - EXA 404. http://www.epa.gov/risk/expobox/tutorials.htm. Accessed 30 Mar 2015.

EPA, 2015. Persistent Organic Pollutants: A Global Issue, A Global Response. http://www2.epa.gov/international-cooperation/persistent-organic-pollutants-global-issueglobal-response. Accessed 11 Sep 2015.

FAO (2013). Statistical Yearbook 2013. http://www.fao.org/docrep/018/i3107e/i3107e00.htm. Accessed 5 May 2015.

Feijtel T.C.J.,. Boeije G, Matthies M., Young A., Morris G., Gandolfi C., Hansen B., Fox K., Holt M. , Koch V., Schroder R. , Cassani G., Schowanek D., Rosenblom J., Niessen H.(1997). Development of geography-referenced regional exposure assessment tool for European rivers-GREAT-ER. Chemosphere (34) : 2351-2373

Fetter E. Krauss M., Brion F. ; Kah O. ; Scholz S.; Brack W. (2014), Effect-directed analysis for estrogenic compounds in a fluvial sediment sample using transgenic cyp19a1b-GFP zebrafish embryos. Aquatic Toxicology (154) : 221-229.

Görlach, B., Landgrebe-Trinkunaite R., Interwies E., Bouzit M., Darmendrail D., Rinaudo J.-D. (2004). Assessing the Economic Impacts of Soil Degradation. Volume IV: Executive Summary. Study commissioned by the European Commission, DG Environment, Study Contract ENV.B.1/ETU/2003/0024. Berlin: Ecologic.

Hawley JK (1985). Assessment of health risk from exposure to contaminated soil. Risk Anal (5) :289-302.

Horta, A., Malone B. , Stockmann U., Minasny B., Bishop T.F.A., McBratney A.B. , Pallasser R., Pozza L. (2015). Potential of integrated field spectroscopy and spatial analysis for enhanced assessment of soil contamination: A prospective review. Geoderma 241-242: 180-209.

Huber S., Prokop A. (2012). Progress in the management of contaminated sites. EIONET Workshop on Soil, Ispra, 10- 12 December 2012. 
INERIS (2009). Valeurs toxicologiques de référence et méthodes de construction pour les effets sensibilisants pour une exposition cutanée. Rapport $N^{\circ}$ INERIS-DRC-09-94380-01323A. http://www.ineris.fr/centredoc/drc070908.pdf. Accessed 10 Sep 2015.

INERIS (2013) - Démarche intégrée pour l'évaluation de l'état des milieux et des risques sanitaires. Rapport NoINERIS- DRC - 12 - 125929 - 13162B. http://www.ineris.fr/centredoc/drc-guide-ers-2013-v4d-complet-lienscompact1378197912.pdf. Accessed 30 March 2015.

INERIS (2014). Substances "émergentes" dans les boues et composts de boues de stations dépurations d'eaux usées collectives-caractérisation et évaluation des risques sanitaires. Rapport NINERIS - DRC-14-115758-08437A. http://www.ineris.fr/centredoc/rapport-ineris--drc-14-115758-08437a---substances-émergentes-dans-les-boues-et-composts-de-boues--vf210115-1430930066.pdf. Accessed 18 Sep 2015.

Jones A., Panagos P., Barcelo S, Bouraoui F., Bosco C., Dewitte O., Gardi C., Erhard, M., Hervas, J., Hiederer, R., Jeffery, S., Lükewille, A., armo, L., Montanarella, L., Ozalabal, C., Petersen, J.E., Penizek, V., Strassburgr, T., Toth, G., Van Den Eeckhaut, M., Van Liederke, M., Verheijen, F., Viestova, E., Yigini, Y. (2012). The State of Soil in Europe: a Contribution of the JRC to the European Environmental Agency's Environment State Outlook report - 2010. Publication Office of the European Union, Luxembourg. http://ec.europa.eu/dgs/jrc//downloads/jrc_reference_report_2012_02_soil.pdf. Accessed 10 Sept 2015.

Kidd P., Mench M., Álvarez-LÓpez V., Bert V., Dimitriou I., Friesl-Hanl W., Herzig R., Janssen J.O., Kolbas A., Müller I., Neu S., Renella G., Ruttens A., Vangronsveld J., Puschenreiter M. (2015) Agronomic Practices for Improving Gentle Remediation of Trace Element-Contaminated Soils, International Journal of Phytoremediation, 17(11):1005-1037, DOI: 10.1080/15226514.2014.1003788V.

Koch A., McBratney A.B., Lal R. (2012). 'Global Soil Week: Put Soil Security on the Global Agenda', Nature 492: 186.

Koch A., McBratney A.B., Adams M., Field D., Hill R., Crawford J., Minasny B., Lal R., Abbott L., O’Donnell A., Angers D., Baldock J., Barbier E., Binkley D., Parton W., Wall D.H., Bird M., Bouma J., Chenu C., Butler F. C., Goulding K., Grunwald S., Hempel J., Jastrow J., Lehman J., Lorenz K., Morgan C.L., Rice C.W., Whitehead D., Young I., Zimmermann M. (2013). Soil Security: Solving the Global Soil Crisis. Global Policy 4(4):434-441.

Lodolo, A., 2015. EUGRIS: Portal for soil and water management in Europe. Further description:Remediation options overview. http://www.eugris.info/FurtherDescription.asp?e=22\&Ca=2\&Cy=0\&T=Remediation\%20option s. Accessed 17 Sep 2015.

MacLeod M, Woodfine DG, Mackay D, McKone T, Bennett D, Maddalena R (2001). Betr North America: a regionally segmented multimedia contaminant fate model for North America. Environ Sci Pollut Res (8): 156-63. 
Malherbe, L. (2002). Designing a contaminated soil sampling strategy for human health risk assessment. Accred. Qual. Assur. 7 (5): 189-194.

Martuzzi M., Mitis F., Bianchi F., Minichilli F., Comba P., Fazzo L. (2009). Cancer mortality and congenital anomalies in a region of Italy with intense environmental pressure due to waste. Occup. Environ. Med., (66): 725-732

Maurau S., Ciffroy P., Brochot C., Roustan Y., Marang L. (2011). Linking multimedia environmental and PBPK models to assess health risks of lead associated to drinking water - A case study. 21. SETAC Europe annual meeting "Ecosystem protection in a sustainable world : a challenge for science and regulation", May 2011, Milan, Italy. <ineris-00970792>. Accessed 13 Sep 2015.

McBratney A.B., Field D.J., Koch A. (2014). The dimensions of soil security. Geoderma, 213, 203213. doi:10.1016/j.geoderma.2013.08.013

McBratney, A.B., Minasny, B., Whelan, B.M., (2011). Defining proximal soil sensing. The Second Global Workshop on Proximal Soil Sensing - IUSS Working Group on Proximal Soil Sensing, Montreal, Quebec, Canada.

Mulligan C.N., Yong R.N., Gibbs B.F.(2001). Remediation technologies for metal contaminated soils and groundwater: an evaluation. Eng. Geol. 60: 193-207.

Murphy B., Hazelton P. (2014). Chapter 5. Advanced tools for interpreting data. In "Contaminated Soils. A Guide to Sampling and Analysis". Maria Gavrilescu and Laura Bulgariu (eds). Future Science Group. Unitec House, 2 Albert Pl, London. (doi: 10.4155/9781909453166).

NORMAN, 2015. The list of currently most frequently discussed emerging substances and emerging pollutants. $\quad \underline{\text { http://www.norman- }}$ network.net/sites/default/files/files/Emerging_substances list April 15/NORMAN\%20list 201 5 Final.xlsx. Accessed 15 Sep 2015.

Panagos P., Van Liederke M., Yigini Y., Montanarella L. (2013). Contaminated sites in Europe: Review of the current situation based on data collected through a European network. Journal of Environmental and Public Health 2013.

Rosén L., Back P., Söderqvist T., Norrman J., Brinkhoff P., Norberg T., Volchko Y., Norin M., Bergknut M., Döberl G. (2015). SCORE: A novelmulti-criteria decision analysis approach to assessing the sustainability of contaminated land remediation. Science of the Total Environment 511: 621-638. http://dx.doi.org/10.1016/j.scitotenv.2014.12.058

Sauvé S., Desrosiers, M. (2014). A review of what is an emerging contaminant. Chem Cent J.; 8: 15.

Science Communication Unit, University of the West of England, Bristol (2013). Science for Environment Policy In-depth Report: Soil Contamination: Impacts on Human Health. Report 
produced for the European Commission DG Environment, September 2013. http://ec.europa.eu/science-environment-policy. Accessed 1 Sept 2015.

State of the Environment Committee (2011). Australia State of the Environment 2011. Independent report to the Australian Government Minister for Sustainability, Environment, Water, Population and Communities , Canberra, Australia. http://www.environment.gov.au/science/soe/2011. Accessed 10 Sept 2015.

Stern, N. (2006). "Summary of Conclusions". Stern Review Report on the Economics of Climate Change. $\quad$ http://siteresources.worldbank.org/INTINDONESIA/Resources/2262711170911056314/3428109-1174614780539/SternReviewEng.pdf. Accessed 21 Sep 2015.

Van-Camp. L., Bujarrabal B., Gentile A-R., Jones, R.J.A., Montanarella, L., Olazabal, C. and. Selvaradjou, S-K. (2004). Report of the Technical Working Groups Established Under the Thematic Strategy for Soil Protection, Monitoring, Vol.5, . Office for Official Publications of the European Communities, Luxembourg.

Viscarra Rossel, R.A., Adamchuk, V.I., Sudduth, K.A., McKenzie, N.J., Lobsey, C., 2011. Proximal soil sensing: an effective approach for soil measurements in space and time. Adv. Agron. (113): 237282.

Viel J-F., Floret N., Deconinck E., Focant J.-F., De Pauw E., Cahn J.-Y (2011). Increased risk of nonHodgkin lymphoma and serum organochlorine concentrations among neighbors of a municipal solid waste incinerator. Environment International (37) : 449-453.

Villanneau E., Saby N., Marchant B.P., Jolivet C., Boulonne L., Caria G., Barriuso E., Bispo A., Briand O., Arrouays D. (2011). Which persistent organic pollutants can we map in soil using a large spacing systematic soil monitoring design? A case study in Northern France. Science of the Total Environment 409 (19):3719-3731.

Weber R., Gaus C., Tysklind M., Johnston P., Forter M., Hollert H., Heinisch E., Holoubek I., LloydSmith M., Masunaga M., Moccarelli P., Santillo D., Seike N., Symons R., Machado Torres J.P., Verta M., Varbelow G., Vijgen J., Watson A., Costner P., Woelz J., Wycisk P., Zennegg M. (2008). Dioxinand POP-contaminated sites-contemporary and future relevance and challenges Overview on background, aims and scope of the series. Environ Sci Pollut Res (15):363-393. DOI $10.1007 / \mathrm{s} 11356-008-0024-1$ 